\title{
ENUNCIAÇÃO E LEITURA
}

Enunciation and reading

\author{
Fernando Moreno da Silva*
}

A ENUNCIAÇÃo

A leitura é fruto do processo da enunciação, atividade compreensível em duas vertentes: comunicação e produção. Na primeira, a enunciação é entendida por meio da relação do fazer-persuasivo de um produtor que quer agir sobre um receptor, encarregado, por seu turno, do fazer-interpretativo. Como se observa, é típico dos estudos da Retórica. Já no que diz respeito à produção, enunciação é um ato de pôr em funcionamento a língua, produzindo um enunciado. ${ }^{1}$ É impossível estudá-la diretamente, porquanto é uma instância lingüística pressuposta pelo enunciado. Mas, como seu produto, o enunciado pode conter traços que reconstituem o ato enunciativo. Esse mecanismo, que consiste em projetar no discurso as marcas de pessoa, tempo e espaço, é conhecido como debreagem, subdividida em dois tipos. A primeira é a debreagem enunciativa, que instala no enunciado as pessoas da enunciação (eu/tu), o espaço da enunciação (aqui) e o tempo da enunciação (agora), produzindo o efeito de sentido da subjetividade. A

* Mestrando em Lingüística e Língua Portuguesa (Unesp/Araraquara), Professor do Instituto Municipal de Ensino Superior de Catanduva/SP - Imes/Fafica.

1 Bakhtin (1992) contrapõe enunciado (unidade ou forma de discurso) a oração ou frase (unidade da gramática). Segundo ele, discurso é um acontecimento, um evento. Não é a parole, pois esta é individual, ao passo que o discurso é social e pertencente ao grupo. Constituindo a realização da língua, ele implica a atualização da fala. Na Análise de Discurso de linha francesa, o discurso é entendido como a manifestação de valores, dentro de formações discursivas. É bom lembrar que Mattoso Câmara traduz parole por discurso, distinguindo nele duas modalidades, de acordo com seu modo de manifestação: "fala" como discurso oral; "escrita" como discurso escrito. 
segunda classificação é a debreagem enunciva, responsável pela instalação das pessoas do enunciado (ele), do espaço do enunciado (lá ou alhures) e do tempo do enunciado (então), criando o efeito de sentido da objetividade.

É preciso que se distingam as nuanças do processo enunciativo. Todo e qualquer enunciado tem como pressuposto o fato de ter sido proferido por alguém num tempo e num espaço. É a idéia da enunciação pressuposta. Quando, nesse enunciado, está presente um “eu”, terá lugar a enunciação-enunciada, correspondendo a uma metáfora da enunciação pressuposta (simulacro similar). Se um "ele", ter-se-á o enunciado-enunciado ou o enunciado propriamente dito, configurando uma metonímia da enunciação pressuposta (de parte em relação ao todo). Mas as categorias de pessoa devem ser esclarecidas.

O "eu" abarca duas instâncias: enunciador e narrador. No primeiro nível da enunciação, está o enunciador: é o "eu" pressuposto, equivalente ao autor implícito. É bom lembrar que autor implícito não é o mesmo que autor real. Ambos, por vezes, coincidem, mas não obrigatoriamente. A figura de carne e osso, pertencente ao mundo extralingüístico, pode fingir, criando, no discurso, a imagem de uma pessoa totalmente diferente de sua autêntica personalidade. Ele não pertence, portanto, ao texto. O enunciador, ao contrário, é uma imagem construída ao longo do texto, uma idealização do ser que produziu o discurso corrente. Traçando um paralelo com a Retórica clássica, cujo princípio preconiza, num ato de comunicação, o envolvimento de três componentes: orador, auditório e discurso. $\mathrm{O}$ enunciador seria, aproximando-o das tradições aristotélicas, o ethos do orador, a voz que ecoa numa construção discursiva.

Enquanto o enunciador é a instância pressuposta que produz o enunciado, o narrador, apresentando-se num segundo nível, é o "eu” projetado no interior do texto, fruto da criação do autor implícito. É uma delegação de voz levada a efeito pelo enunciador. Para melhor o entender calha o princípio do foco narrativo. Dentre as diversas classificações, as mais genéricas são:

a) narrador onisciente: enredo narrado em terceira pessoa, o narrador tudo sabe, comenta e avalia;

b) narrador-observador: narrado em primeira pessoa, não participa diretamente dos acontecimentos;

c) narrador-personagem: narra o enredo participando dos acontecimentos. 
A fim de aclarar a distinção entre enunciador e narrador, recorrese ao poema I-Juca-Pirama, de Gonçalves Dias (1985, p. 119-122):

Meu canto de morte, Guerreiros, ouvi:

Sou filho das selvas, Nas selvas cresci; Guerreiros, descendo Da tribo tupi.

(Poesias de Gonçalves Dias. Rio de Janeiro: Edições de Ouro, 1985)

Nesse trecho, vê-se claramente um "eu" que perpassa o poema. Na superfície textual, o "eu" é figura pelo índio tupi, que é o narrador. Já o enunciador constrói-se como uma instância subjacente à manifestação; uma voz preocupada e crítica que procura exaltar a figura do índio, convocando e sensibilizando os sentimentos de um povo para com sua natureza.

Um último e terceiro nível surge quando o narrador delega voz aos actantes do enunciado. Neste ensejo, aquele que fala se transforma no interlocutor. Na terminologia dos estudos literários, é a fala dos personagens. O sinal marcante para essa distinção é o uso do discurso direto. $O$ espaço dado aos personagens é introduzido pelo mecanismo da debreagem interna ou de segundo grau, prestando-se a criar o efeito de sentido de realidade, pois parece que o próprio personagem toma a palavra:

o discurso direto, em geral, cria um efeito de sentido de realidade, pois dá a impressão de que o narrador está apenas repetindo o que disse o interlocutor. Tanto esse fato é verdadeiro que, quando se narra em discurso direto, o que se pergunta ao narrador é se o interlocutor disse com aquelas palavras mesmo (FIORIN, 1994, p. 79).

Conhece-se, então, uma quarta modalidade da enunciação. Dando a palavra a outrem, o narrador institui a enunciação reportada, que é um simulacro de enunciação. O interlocutor também pode ser o próprio narrador, na ocasião em que ele faz uso do travessão para expressar um eventual sentimento, caso típico quando se recorre a uma interjeição. 
As FACES DO LEITOR

Até aqui, discorreu-se apenas sobre um "lado da moeda". Sabe-se que, em todo processo de comunicação, a um "eu" corresponde sempre um "tu". Por isso, diante do enunciador está o enunciatário; do narrador, o narratário; do interlocutor, o interlocutário.

Na produção enunciativa, o enunciador invariavelmente considera a quem se destina seu discurso. Como numa comunicação epistolar, na qual se escreve sempre pensando naquele que irá ler a carta. Caso contrário, o discurso não alcança eficácia. Se, num desfile de modas, apresentamse modelos de roupas incrementados com peles de animais diante de uma platéia de ecologistas ou ambientalistas, certamente haverá protestos. Por ser levado em conta na construção do enunciado, afinal ele é a razão de existir do discurso, havendo diálogo entre emissor e receptor, o enunciatário faz parte do processo produtivo, constituindo-se um co-enunciador. Daí ser válida a asserção de que o sujeito da enunciação é composto por enunciador e enunciatário, já que este último influi visceralmente na forma e no conteúdo.

O enunciatário seria, nesse propósito, um destinatário implícito da mensagem, o leitor ideal. Muitos autores o têm denominado de formas variadas, mas todas conservam o mesmo significado: $\mathrm{W}$. Iser emprega "leitor implícito"; J. Lintvelt, "leitor abstrato"; Umberto Eco, "leitor modelo". E mais uma vez é necessária a ressalva de que não se deve confundir o leitor virtual com o leitor empírico de carne e osso. Entre um ensaio filosófico e a narrativa do Chapeuzinho Vermelho é fácil construir a imagem dos seus respectivos leitores: para o primeiro, estariam os leitores críticos, ao passo que, ao segundo, o público infantil. Esta é, grosso modo, uma projeção dos leitores virtuais, mas nada impede que, na prática, um pesquisador vá ler um enredo infantil a fim de pesquisa. Mas, no presente trabalho, a preocupação é com o leitor ideal, aquele que é pressuposto pela obra. Pelos leitores reais se interessam, na maioria das vezes, os sociólogos ou publicitários. Ainda que se insista nesta diferenciação, não há dúvidas de que o espaço do enunciatário será fatalmente preenchido por um leitor de carne e osso.

Como destinatário do narrador está o narratário. Esse "tu" definido pelo texto apresenta-se de duas formas:

a) narratário-personagem ou intradiegético (dentro da diegese, ou seja, o mundo da história): quando participa diretamente da narrativa. Como exemplo, um trecho do poema Inexorável, de Cruz e Souza. Nele, o narratário está no papel da amada falecida: 
Ó meu Amor, que já morreste, Ó meu Amor, que morta estás! Lá nessa cova a que desceste ó meu Amor, que já morreste, Ah! Nunca mais florescerás?

(Poesias completas. Rio de Janeiro: Ediouro, [s.d.]. p. 57)

b) narratário interpelado: um anônimo a quem o narrador se dirige, não sendo personagem da narrativa:

Esta idéia para um conto de terror é tão terrível que, logo depois de tê-la, me arrependi. Mas já estava tida, não adiantava mais. Você, leitor, no entanto, tem uma escolha. Pode parar aqui, e se poupar, ou ler até o fim e provavelmente nunca mais dormir.

[...]

Você, leitor, já deve estar sentindo o que vai acontecer. Pare de ler, leitor. Eu não posso parar de escrever...

(VERÍSSIMO, 2001, p. 33-35)

E ao interlocutor corresponde o interlocutário, igualmente um destinatário instalado, pelo narrador, dentro do discurso direto. Num diálogo, por exemplo, com travessão dentro de uma narrativa, interlocutor e interlocutário se invertem a cada momento em que um deles toma a palavra. Aquele que fala é o interlocutor, e aquele que ouve, o interlocutário.

\section{O PROCESSO DE LEITURA}

Como se pode perceber, o leitor deixa de ser considerado uma entidade passiva, uma vez que participa indiretamente do complexo de produção discursiva. O processo da leitura, destarte, compreende dois estágios ou, em outros termos, duas atividades no interior do ato: compreensão e interpretação. Inicialmente, o leitor atua na decodificação ${ }^{2}$ da superfície discursiva, englobando as organizações mórficas, sintáticas e semânticas.

2 Pela derivação prefixal (acréscimo do prefixo "des”), formou-se o vocábulo "descodificação, que, mediante o processo fonológico da síncope (supressão de fonema no interior da palavra), recebeu posteriormente a forma paralela "decodificação", consagrada pelo uso. 
Exige-se na compreensão o reconhecimento intradiscursivo das regras de uso da língua natural. Num momento subseqüente, aprofundando a leitura, está a interpretação, que demanda um trabalho maior por parte do leitor, pois será necessário debruçar-se sobre as motivações ideológicas e inconscientes do texto, numa relação intertextual. Lopes (1978, p. 53) assim a concebe: "Ao trajeto que, partindo de um plano de expressão plurissignificacional, conotado, tem por ponto de chegada um único efeito-de-sentido denotado, chamamos interpretação".

Todo enunciado produzido está imerso numa formação ideológica e numa formação discursiva, além de ser uma soma de outros discursos. Há uma complexidade em torno da idéia de sujeito. o "eu" é formado por uma ideologia que, por seu turno, é formada por um feixe de fios ideológicos. Duas pessoas têm valores em comum, mas também valores opostos. Por conseguinte, a competência de leitura está intimamente relacionada ao conhecimento enciclopédico do leitor; ele absorve um texto de acordo com sua vivência, aí incluídos "n" fatores: lingüístico, cultural, religioso, etc. É o que observa Cortina (1994, p. 51):

...se existir alguma falha na observação dos elementos que constituem a superfície discursiva de um texto, que corresponde à relação intradiscursiva (compreensão), ou na captação dos registros do conhecimento, isto é, de outros textos ou outras culturas, que corresponde à relação intertextual (interpretação), o ato de leitura será prejudicado, ou, no mínimo, alterado.

Um bom exemplo da participação impreterível do leitor na produção de sentido apresenta-se na construção de sentido do riso. Este efeito, muitas vezes, não está inscrito na superfície textual, mas é uma sensação suscitada pela construção discursiva no destinatário da mensagem:

\author{
CAMBRONNIANA \\ a bom entendedor \\ meia palavra: bos- \\ (PAES, 1988, p. 32)
}

O riso suscitado nesse trecho não advém apenas da referência a um provérbio. Este é apenas um meio para se construir o sentido de uma palavra cindida: bosta. Para a interpretação real desse recurso, ao leitor é exigido um conhecimento de mundo para depreender, mediante uma leitura 
intertextual, que se trata de uma paródia endereçada ao engenheiro francês Charles Louis Cambronne, que foi responsável pela instalação do sistema de esgotos em Recife.

Indubitavelmente, há outras influências sobre o processo interpretativo, como o contexto. Significados distintos pode haver conforme o ambiente considerado. Duas concepções se referem a ele.

o contexto interno ou lingüístico, no sentido estrito do termo, é o encadeamento de significantes num eixo sintagmático. Ele é importante para o valor semântico da palavra. O vocábulo "tênis", em estado de dicionário, é polissêmico, possibilitando vários usos. Neste estado, Bakhtin (1979) afirma ser a palavra neutra, porque cria condições de receber novos valores dependendo do contexto. Quando atualizada pelo discurso, as acepções da partícula são especificadas:

a) como sinônimo de calçado: "Ele comprou um lindo tênis para caminhar"

b) como modalidade esportiva: "O campeonato de tênis deste ano vai reunir os melhores tenistas do mundo".

No contexto exterior ou extralingüístico, está a situação espaciotemporal. A sociolingüística a denomina "situação imediata", conforme descreve as variações estilísticas ou registros, que são as variações da fala de um mesmo indivíduo em diferentes ambientes. A fala sui generis de um advogado num tribunal ou num congresso seria ridícula se, porventura, fosse empregada num bate-papo descontraído no bar: "Excelentíssimo senhor garçom, poderia, por obséquio, trazer-me, inicialmente, uma exígua porção de aguardente para que eu possa depois degustar uma bebida fermentada à base de cevada?". Portanto, o estilo de fala se molda à situação na qual se encontra o falante.

Um outro caso ocorre quando a produção e a recepção do enunciado não são contemporâneas. Nesta especificidade, a descontextualização é a causa da pluralidade de leituras.

$\mathrm{Na}$ comunicação oral, em virtude da recorrência a remissões da situação imediata e do comportamento não-verbal, há economia de procedimentos lingüísticos. Na comunicação escrita, entretanto, quando autor e leitor estão em épocas peculiares, distantes no tempo e no espaço, a única fonte de leitura é o próprio texto. Aí surgem os problemas, conforme observa Amaral (2002, p. 74): "Percebemos, então, que a questão da leitura é também uma questão do leitor, já que o sentido pode estar tanto no interior quanto no exterior do texto e é no movimento da história que vamos fazer esta ou aquela leitura". 
A obra de Nicolau Maquiavel, $O$ príncipe, cuja primeira edição data de 1532, recebeu, por exemplo, várias leituras, muitas vezes conflitantes. Basicamente, nela se ensina como um príncipe deve proceder para conquistar e assegurar o poder. Seria, por alto, um manual de técnicas instrumentais da autocracia. Ainda no século XVI, a Igreja Católica, com o movimento da Contra-Reforma, não vê com bons olhos a obra, proscrevendo-a ao incluí-la no Índice de Livros Proibidos. O argumento era de que havia no livro princípios contrários aos ensinamentos de Cristo. No século XVII, com a ascensão das monarquias absolutistas nos novos Estados europeus, o livro ganha o sentido talvez maquinado pelo próprio Maquiavel: servir de instruções aos métodos despóticos. Em pleno Iluminismo, Jean-Jacques Rousseau, n'o contrato social, interpretará o livro maquiavélico como positivo, contrapondo-se às abordagens até então levantadas. Para o escritor francês, a obra desmascara o abuso de poder dos príncipes, afirmando ser o interlocutor do livro não o príncipe italiano Lorenzo II, mas o povo.

$\mathrm{Na}$ tentativa de compreender o processo de leitura, Eco (2001) estabelece uma tríade: intenção do autor (intentio auctoris), intenção do leitor (intentio lectoris) e intenção do texto (intentio operis). Certamente, ao tocar em algum destes pontos sobrevêm polêmicas. Em toda a história da análise de textos sempre vigorou a idéia de que o analista deveria intentar descobrir exatamente qual seria o desígnio do autor real. Nessa busca pela intenção do sujeito-produtor do discurso, ler era uma investigação empírica, afinal o leitor submetia-se à autoridade autoral. Além do texto, a preocupação era desvendar a vida pessoal do autor, com suas tendências e predileções. Essa obsessão beirava, às vezes, o misticismo. A exegese de escritos psicografados era autorizada tão-só a um médium, cuja revelação, conforme as crenças, fora uma dádiva.

Esta tendência de pautar-se pela autoridade suprema do autor foi preponderante até o século XIX, pois, a partir de 1916, com as compilações de Charles Bally, Albert Sechehaye e colaboração de Albert Riedlinger, todos discípulos de Ferdinand de Saussure, foi inaugurada a Lingüística moderna, com o livro Curso de lingüística geral. Até então, a relação entre língua e mundo era assaz forte. Predominava a controvérsia de duas vertentes gregas. Os analogistas, com o aval de Aristóteles, defendiam que a interrelação mundo/língua era natural, ou seja, a língua denominava o mundo, refletia-o, sendo, pois, um sistema regular governado por leis. Afirmando a semelhança, para eles apenas uma língua-mãe existia, que, com o tempo, foi adaptada e ramificada a outros idiomas. Em contraposição, estavam os anomalistas, preconizando a convenção à frente da vinculação mundo/língua, pois o sistema lingüístico é uma coleção de exceções, dominado, em toda a extensão da palavra, pela irregularidade. Estas eram as idéias clás- 
sicas de língua. Com o advento do estruturalismo, houve um corte ou uma ruptura na concepção do vínculo língua/mundo. O lingüista suíço Saussure demonstra que a língua pode definir-se per se, como um sistema autônomo, uma vez que ela é uma abstração. Assim, a visão imanentista, justamente centrada na intenção do texto, ganha magnitude, assistindo a seu zênite nos decênios de sessenta e setenta do século pretérito, sobretudo com as pesquisas universitárias. Importa, também, neste julgamento, "como" a significação é construída; não simplesmente "o quê", da forma como se dá numa descrição parafrástica.

Uma terceira visão sobre leitura, a vertente mais moderna, recai sobre a intenção do leitor. A partir desta nova abordagem, o leitor exime-se da imagem de atuação passiva. Como se viu anteriormente, avulta seu papel ativo como parte da escalada produtiva. Do ponto de vista da produção, seria inconcebível, caso se queira elaborar um texto eficiente, não levar em conta a quem ele se destina. Do outro lado, ou seja, na perspectiva da recepção, o leitor ganha autonomia em sua interpretação. Não se diz que há a leitura certa ou errada, mas o ponto de vista de quem o lê, porque, num texto, coexistem várias leituras. Mas isso não quer dizer que qualquer uma é verdadeira. o significado deve estar ancorado no texto, caso contrário, chegar-se-ia ao extremo de afirmar que o discurso não tem importância, já que qualquer interpretação é válida. "Ler não é se deixar levar pelos caprichos de seu próprio desejo/delírio interpretativo, pois se se pode ler qualquer coisa atrás de qualquer texto... então todos os textos se tornam sinônimos" (KERBRAT-ORECCHIONI, apud JOUVE, 2002, p. 25).

\section{CONCLUSÃo}

Por leitor, portanto, depreende-se uma instância complexa. Sob o ponto de vista da enunciação, a instância ocupada por ele pode ser definida em dois aspectos: comunicação e produção. Levando em consideração a enunciação, sob a ótica da comunicação, o enunciatário seria simplesmente um destinatário. Nesse primeiro momento, ele é, grosso modo, uma posição sintática, considerado um actante da enunciação. Com base na teoria da informação, elaborada por Shannon, posteriormente retomada por Jakobson no modelo da comunicação verbal, sua posição se enquadra no caráter simplista da recepção, ou seja, o "tu" ao qual um "eu" se dirige, funcionando como destino da comunicação.

Num segundo estágio, no tocante à produção enunciativa, como se viu, o enunciatário representaria um partícipe da produção discursiva, 
recebendo o papel de co-enunciador. Isso se dá porque o enunciador, para atingir a eficácia de seu discurso, indubitavelmente necessita considerar seu destinatário. Escrever para um grupo de crianças não é a mesma coisa que produzir um texto para filósofos. Trocando em miúdos, a atribuição de "co-autoria" dada ao enunciatário é válida porquanto ele rege o rumo da constituição discursiva, pois constitui a imagem à qual o enunciador se dirige. Nesta concepção de imagem, que não concebe o leitor real, mas uma entidade ideal, ele ganha um revestimento temático-figurativo, transformandose em ator da enunciação. Por essa razão, ambas as instâncias - enunciador e enunciatário - integram o termo "sujeito da enunciação", já que estão em sincretismo.

Posteriormente, na leitura propriamente dita, o destinatário da mensagem é responsável pela atualização do conteúdo textual e pela produção de sentidos, dentro dos processos de compreensão e interpretação. Nesse terceiro momento, surge a figura do leitor empírico, num processo prático. $\mathrm{O}$ ato de ler é, na verdade, uma dobradinha: leitor e produtor de texto. Isso ocorre porque a leitura o torna um sujeito competente para a construção de um objeto-valor cognitivo: o discurso. $\mathrm{O}$ ato de leitura, além de instituir a figura do leitor, é uma prévia, uma antecipação daquele que virá a ser o autor empírico de fato. Retomando as teses bakhtinianas do princípio dialógico, o autor nada mais é do que um leitor que se apodera de inúmeros textos a fim de compor, a posteriori, um novo texto. É o princípio do dialogismo regendo a linguagem.

\title{
RESUMO
}

O presente artigo tem como objetivo refletir sobre o processo de leitura sob o ponto de vista da enunciação. Entender os vários níveis da enunciação (enunciador/enunciatário, narrador/ narratário e interlocutor/interlocutário) é também compreender o papel do leitor na produção discursiva, ou seja, como coprodutor, sendo englobado no conceito de sujeito da enunciação.

Palavras-chave: enunciação; leitura; semiótica.

\begin{abstract}
This article has the aim to reflect over the process of reading under the enunciation point of view. Understanding the
\end{abstract}


different levels of enunciation (enunciator / enunciatee, narrator / narratee, interlocutor / interlocutee) is also comprehending the role of the reader in the production of the discours, as a co-productor, found in the concept of the subject of enunciation.

Key-words: enunciation; reading; semiotics.

\section{REFERÊNCIAS}

BAKHTIN, Mikhail. Marxismo e filosofia da linguagem. São Paulo: Hucitec, 1979.

CORTINA, Arnaldo. Leitura como processo de compreensão e de interpretação: "O Príncipe" e seus leitores. São Paulo, 1994. Tese (Doutorado) - Universidade de São Paulo.

FIORIN, José Luiz. As astúcias da enunciação: as categorias de pessoa, espaço e tempo. São Paulo, 1994. Tese (Livre-docência) - Faculdade de Filosofia, Letras e Ciências Humanas, Universidade de São Paulo.

LOPES, Edward. Discurso, texto e significação: uma teoria do interpretante. São Paulo: Cultrix, 1978.

PAES, José Paulo. A poesia está morta mas juro que não fui eu. São Paulo: Duas Cidades, 1988. (Coleção Claro Enigma).

VERÍSSIMO, Luís Fernando. Comédias para se ler na escola. Rio de Janeiro: Objetiva, 2001. 